\title{
ONTOLOGICAL ANALYSIS OF THE PROJECT RISK MANAGEMENT CONCEPT 'RISK'
}

\author{
Juris UZULĀNS \\ University of Latvia, Riga, Latvia \\ Corresponding authore-mail: jouris@latnet.lv
}

\begin{abstract}
The aim of the current research series is to examine the definitions of the concept 'risk' and analyze the concepts used in the definitions of 'risk' in the sources of these definitions in order to perform the ontological analysis of the concept of 'risk'. Ontological and epistemological analysis of the concepts in the definition of the concept 'risk' was used to answer the question what 'risk' means in project management. This investigation represents a part of the research series where the ontological, epistemological and methodological analysis of project risk is performed with the aim to improve risk registers and risk management as a whole. In the previous studies the author analyzed the concept of 'event' that defines the content of the concept 'risk'. The use of 'event' was analyzed in different sources to find out how the concept should be used. The ontological, epistemological and methodological analysis of the definitions of the concept 'risk' is the theoretical foundation for risk register creation because it is possible to create complete and understandable register for the participants of the project risk management process. The author believes that the conducted research helps establish confidence that ontological analysis is the method that together with the epistemological and methodological analysis provides opportunity to perform analysis of risk management sources aimed at improving risk management. The results of the study cannot be considered sufficient for deriving valid conclusions about project risk management and developing recommendations for improving risk management with regard to the content of the risk register. For valid conclusions and recommendations, a deeper research is needed which, first of all, would analyze a larger number of sources.
\end{abstract}

Keywords: concept, event, ontological analysis, project, project risk register, risk.

\section{INTRODUCTION}

Risk management is an important element of project management. Qualitative risk management provides for a full-fledged risk identification, risk analysis and management. The risk register represents a significant risk management document that summarizes the identified risks, results of risk analysis and management. Identification of risks is not easy; however, it can be relieved by understanding the concept of 'risk' in project management. For this reason, it is important to study the definitions of the concept 'risk' by analyzing the concepts used in its definitions. 


\section{RESEARCH METHODOLOGY}

The study is based on the use of qualitative research methods. Taking into account the size constraints of the article, initially 25 sources were selected out of 120 , which had been previously chosen for a more comprehensive study. A generator of random numbers was used for the selection of the sources (www.random.org).

During the research, one of the sources was excluded because it was not suitable for the study. Each of the sources contained a definition of 'risk', 23 sources were in Adobe Acrobat pdf format and two - in Microsoft Word doc. All sources, except for four books by definite authors, were publicly available online in July, 2017. The content of the first book is partly available in the online Google Books site, the content of 3 books is not available in Google Books. The definitions and sources were analyzed in accordance with the ontological categories.

The term 'ontology' is defined in the English Oxford Living Dictionaries (en.oxforddictionaries.com) as "The branch of metaphysics dealing with the nature of being", in the Cambridge Dictionary (dictionary.cambridge.org): "the part of philosophy that studies what it means to exist", in the Macmillan Dictionaries (www.macmillandictionary.com): "the type of philosophy that deals with the study of existence" and in the Merriam-Webster dictionary (www.merriam-webster.com) the first meaning is "a branch of metaphysics concerned with the nature and relations of being", the second "a particular theory about the nature of being or the kinds of things that have existence".

For the study purposes, the author used the Find and Advanced search function of programme Adobe Acrobat Reader DC 2017 Release as well as the Concordance, Clusters/N-Grams, Collocates and Word List functions of AntConc 3.4.4w (Windows) and Search functions of Microsoft Word. Applications Adobe Acrobat Reader and AntConc are available online free of charge. To use the AntConc application for analyzing the definitions of the concept 'risk', each definition was saved in a separate text file thus together creating 25 text files. One of the sources could not be used in the research, because the concept 'risk' was not defined unequivocally. The remaining 22 sources were first of all analyzed in their original format of Adobe Acrobat Reader DC and two sources in their original format of Microsoft Word. Secondly, to use the AntConc application for the analysis of the concepts used in the definitions of 'risk', 22 files were transformed into text files with the help of functions Save as Other of Adobe Acrobat Reader DC by choosing Text and two files into text files with the help of functions Save as Other of Microsoft Word.

\section{FINDINGS / RESULTS}

According to AntConc, there were 573 words in the definitions of the concept 'risk', 166 of them are original. 10 most commonly used nouns, verbs, adjectives and adverbs are as follows: project -25 , event -15 , risk -15 , is -14 , negative -9 , objectives -9 , effect -8 , has -8 , uncertain -8 , condition -7 . 
In each of the definitions of 'risk', there is one or more concepts, which determine the volume of the concept 'risk'. These concepts can be named the concepts determining the content of the defined concept, or the decisive concepts. Table 1 presents the concepts determining the definitions of the concept 'risk'.

Table 1. The concepts determining the definitions of the concept 'risk'

\begin{tabular}{|c|c|c|}
\hline No. & Definition & $\begin{array}{l}\text { Decisive } \\
\text { concept or } \\
\text { concepts }\end{array}$ \\
\hline 1. & $\begin{array}{l}\text { The implications of uncertainty about the level of project performance } \\
\text { achievable (Chapman \& Ward, 2003) }\end{array}$ & implications \\
\hline 2. & $\begin{array}{l}\text { The chance that an undesirable project event will occur and the } \\
\text { consequences of all its possible outcomes (Larson \& Gray, 2011) }\end{array}$ & chance \\
\hline 3. & $\begin{array}{l}\text { Risk is a measure of the probability and consequence of not achieving a } \\
\text { defined project goal (Kerzner, 2009) }\end{array}$ & $\begin{array}{c}\text { measure, } \\
\text { consequence }\end{array}$ \\
\hline 4. & $\begin{array}{l}\text { The chance of something happening that will have an impact upon } \\
\text { objectives. It is measured in terms of consequences and likelihood. In } \\
\text { some situations, risk arises from the possibility of deviation from an } \\
\text { expected outcome or event, such as a deviation from the project plan. The } \\
\text { consequences may be positive or negative (Cooper et al., 2005) }\end{array}$ & chance \\
\hline 5. & $\begin{array}{l}\text { Any event which is likely to adversely affect the ability of the project to } \\
\text { achieve the defined objectives (Method } 123,2003 \text { ) }\end{array}$ & event \\
\hline 6. & $\begin{array}{l}\text { Risk is the potential effect of uncertainty on project objectives } \\
\text { (PM4NGOs, 2013) }\end{array}$ & effect \\
\hline 7. & $\begin{array}{l}\text { The exposure of stakeholders to the consequences of variation in outcome } \\
\text { (Association for Project Management, 2006) }\end{array}$ & exposure \\
\hline 8. & $\begin{array}{l}\text { External factors and events that could affect the progress or success of the } \\
\text { project (International Labour Organization, 2015) }\end{array}$ & $\begin{array}{l}\text { factors, } \\
\text { events }\end{array}$ \\
\hline 9. & $\begin{array}{l}\text { An uncertain event or condition that, if it occurs, has a positive or negative } \\
\text { effect on a project's objectives (Official PM Book for AAPM, 2014). }\end{array}$ & $\begin{array}{l}\text { event, } \\
\text { condition }\end{array}$ \\
\hline 10. & $\begin{array}{l}\text { Risk is the chance that an event will prevent, or negatively affect the } \\
\text { chances of, a project achieving its objective (Organization for Security and } \\
\text { Co-operation in Europe, 2010) }\end{array}$ & chance \\
\hline 11. & $\begin{array}{l}\text { Risk is the probability that an event or action may adversely affect the } \\
\text { achievement of project objectives or activities. Risks are composed of } \\
\text { factors internal and external to the project, although focus is generally } \\
\text { given to those factors outside project management's direct control } \\
\text { (European Commission, 2004) }\end{array}$ & probability \\
\hline 12. & $\begin{array}{l}\text { Risk refers to an uncertain event that affects the objective of a project that } \\
\text { is about to start and includes results and extent of influence it may cause } \\
\text { (Ohara, 2005) }\end{array}$ & event \\
\hline 13. & $\begin{array}{l}\text { An uncertain event or condition that, if it occurs has a positive or negative } \\
\text { effect on a project's objectives (City Of Tampa - Department of } \\
\text { Technology and Innovation, n.d.) }\end{array}$ & $\begin{array}{l}\text { event, } \\
\text { condition }\end{array}$ \\
\hline 14. & $\begin{array}{l}\text { Risk is a function of the likelihood of a loss weighted by its severity (The } \\
\text { American Institute of Architects, 2007) }\end{array}$ & function \\
\hline 15. & $\begin{array}{l}\text { A measure of future uncertainties in achieving program performance goals } \\
\text { within defined cost and schedule constraints. It has three components: a } \\
\text { future root cause, a likelihood assessed at the present time of that future } \\
\text { root cause occurring, and the consequence of that future occurrence } \\
\text { (Department of Defense, 2006) }\end{array}$ & measure \\
\hline 16. & $\begin{array}{l}\text { A factor, element, constraint, or course of action on a project that } \\
\text { introduces an uncertainty of outcome and the possibility of technical }\end{array}$ & $\begin{array}{l}\text { factor, } \\
\text { element, }\end{array}$ \\
\hline
\end{tabular}




\begin{tabular}{|c|l|c|}
\hline & $\begin{array}{l}\text { deficiencies, inadequate performance, schedule delays, or cost overruns } \\
\text { that could impact a mission. In the evaluation of project risk, the potential } \\
\text { negative or positive impacts and the probability of occurrence must be } \\
\text { considered (U.S. Department of Energy, 2004) }\end{array}$ & $\begin{array}{c}\text { constraint, } \\
\text { course of } \\
\text { action on a } \\
\text { project }\end{array}$ \\
\hline 17. & $\begin{array}{l}\text { Project risk is an uncertain event or condition that, if it occurs, has a } \\
\text { positive or negative effect on at least one project objective (U.S. } \\
\text { Department of Justice, 2015) }\end{array}$ & $\begin{array}{c}\text { event, } \\
\text { condition }\end{array}$ \\
\hline 18. & $\begin{array}{l}\text { Reasoned assessment of the potential inability to achieve project } \\
\text { objectives within defined cost, schedule institutional and technical } \\
\text { constraints (U.S. Department of Transportation, 2017) }\end{array}$ & assessment \\
\hline 19. & $\begin{array}{l}\text { An uncertain event that could affect the program positively or negatively. } \\
\text { Risk and its outcomes can be quantified in some definite way (U.S. } \\
\text { Government Accountability Office, 2015) }\end{array}$ & event \\
\hline 20. & $\begin{array}{l}\text { Risk is an event or condition that may cause a negative effect on a project } \\
\text { (Program Management Office (PMO), 2002) }\end{array}$ & $\begin{array}{c}\text { event, } \\
\text { condition }\end{array}$ \\
\hline 21. & $\begin{array}{l}\text { A risk is any factor that has the possibility of causing harm and/or loss to } \\
\text { the project (Missouri Information Technology Advisory Board, 2003) }\end{array}$ & factor \\
\hline 22. & $\begin{array}{l}\text { An uncertain event or condition that, if it occurs, has a negative or positive } \\
\text { effect on at least one project objective (Department of Transportation, } \\
\text { 2017) }\end{array}$ & $\begin{array}{c}\text { event, } \\
\text { condition }\end{array}$ \\
\hline 23. & $\begin{array}{l}\text { Uncertain event or condition that, if it occurs, has a positive or negative } \\
\text { effect on a project's objectives (Transportation Research Board, 2010) }\end{array}$ & $\begin{array}{c}\text { event, } \\
\text { condition }\end{array}$ \\
\hline 24. & $\begin{array}{l}\text { Project risk is an uncertain event or condition that, if it occurs, has a } \\
\text { positive or negative effect on a project's objectives (ND Enterprise Project } \\
\text { Management Advisory Group, 2009) }\end{array}$ & $\begin{array}{c}\text { event, } \\
\text { condition }\end{array}$ \\
\hline Source: Compiled by the author
\end{tabular}

Source: Compiled by the author

In 11 definitions, or $46 \%$ of all the definitions, the decisive concept is 'event' or 'events', in 3 definitions the only decisive concept and the second most often used one is 'chance'. In 10 definitions, there are several decisive concepts -7 definitions include the concepts 'event' and 'condition'. Overall, all definitions are comparable as the structure of definitions is similar. The first part establishes what 'risk' is: "risk is ...", the second part limits the scope of the decisive concept, "the limiter - the decisive concept", or "the decisive concept - the limiter".

The assessment of the concepts limiting the scope of the decisive concept by selected categories suggests that most of the limiters correspond to the categories of action and quality. Table 2 summarizes information about the limiter/limiters of the scope of the decisive concept and provides their assessment in compliance with the ontological categories.

Table 2. Information about the limiter/limiters

\begin{tabular}{|c|c|c|c|}
\hline No. & $\begin{array}{l}\text { Decisive concept or } \\
\text { concepts }\end{array}$ & $\begin{array}{l}\text { Limiter/limiters of the } \\
\text { decisive concept volume }\end{array}$ & $\begin{array}{c}\text { Assessment of the } \\
\text { limiter/limiters of the } \\
\text { decisive concept volume by } \\
\text { ontological category }\end{array}$ \\
\hline 1. & implications & ... of uncertainty & action \\
\hline 2. & chance & $\begin{array}{l}\text {... that an undesirable } \\
\text { project event }\end{array}$ & action \\
\hline 3. & $\begin{array}{c}\text { measure } \\
\text { consequence }\end{array}$ & $\begin{array}{l}\ldots \text { of the probability } \\
\ldots \text { of not achieving }\end{array}$ & $\begin{array}{l}\text { quantity } \\
\text { action }\end{array}$ \\
\hline 4. & chance & ... of something & action \\
\hline
\end{tabular}




\begin{tabular}{|c|c|c|c|}
\hline 5. & event & any ... & quantity or quality \\
\hline 6. & effect & potential ... & quality \\
\hline 7. & exposure & ... of stakeholders & action \\
\hline 8. & factors, events & external & quality \\
\hline 9. & event, condition & uncertain ... & quality \\
\hline 10. & chance & ... that an event & action \\
\hline 11. & probability & $\ldots$ that an event & action or relation \\
\hline 12. & event & uncertain ... & quality \\
\hline 13. & event, condition & uncertain ... & quality \\
\hline 14. & function & $\begin{array}{c}\ldots \text { of the likelihood of a } \\
\text { loss weighted by its } \\
\text { severity }\end{array}$ & relation? \\
\hline 15. & measure & ... of future uncertainties & action \\
\hline 16. & $\begin{array}{l}\text { factor, element, constraint, } \\
\text { course of action on a project }\end{array}$ & ... that introduces & action \\
\hline 17. & event, condition & uncertain ... & quality \\
\hline 18. & assessment & $\begin{array}{l}\text { Reasoned ... of the } \\
\text { potential inability }\end{array}$ & quality \\
\hline 19. & event & uncertain & quality \\
\hline 20. & event, condition & -- & -- \\
\hline 21. & factor & any .... & quantity or quality \\
\hline 22. & event, condition & uncertain ... & quality \\
\hline 23. & event, condition & uncertain ... & quality \\
\hline 24. & event, condition & uncertain ... & quality \\
\hline
\end{tabular}

Source: Compiled by the author

Table 3 summarizes the use of the definition and the decisive concept. The number of times the concept was used was established with the help of Advanced Search function of the programme Adobe Acrobat Reader DC 2017 Release.

Table 3. The use of the definition and the decisive concept

\begin{tabular}{|c|c|c|c|c|c|}
\hline No. & $\begin{array}{c}\text { Decisive } \\
\text { concept or } \\
\text { concepts }\end{array}$ & $\begin{array}{c}\text { Presence } \\
\text { of } \\
\text { definition }\end{array}$ & $\begin{array}{l}\text { Number of } \\
\text { times used }\end{array}$ & $\begin{array}{l}\text { Limiter/-s of the } \\
\text { decisive concept }\end{array}$ & $\begin{array}{l}\text { Number of } \\
\text { times of the } \\
\text { concept use }\end{array}$ \\
\hline 1. & implications & no & 133 & ... of uncertainty & 699 \\
\hline 2. & chance & no & 56 & $\begin{array}{l}\ldots \text { undesirable } \\
\text { project event }\end{array}$ & $\begin{array}{c}1 \\
\text { project event } 7 \\
\text { event } 307\end{array}$ \\
\hline 3. & $\begin{array}{c}\text { measure } \\
\text { consequence }\end{array}$ & no & $\begin{array}{l}37 \\
74\end{array}$ & $\begin{array}{l}\ldots \text { of the probability } \\
\ldots \text { of not achieving }\end{array}$ & $\begin{array}{c}209 \\
38\end{array}$ \\
\hline 4. & chance & no & 22 & ... of something & 10 \\
\hline 5. & event & no & 2 & any ... & 13 \\
\hline 6. & effect & no & 11 & $\begin{array}{c}\text { potential ... of } \\
\text { uncertainty }\end{array}$ & $\begin{array}{c}55 \\
3 \\
\end{array}$ \\
\hline 7. & exposure & no & 5 & ... of stakeholders & 66 \\
\hline 8. & $\begin{array}{l}\text { factors } \\
\text { events }\end{array}$ & no & $\begin{array}{l}19 \\
26\end{array}$ & external ... & 63 \\
\hline 9. & $\begin{array}{c}\text { event } \\
\text { condition }\end{array}$ & $\begin{array}{c}\text { risk event } \\
\text { no }\end{array}$ & $\begin{array}{l}4 \\
1\end{array}$ & uncertain ... & 1 \\
\hline 10. & chance & no & 1 & ... that an event & 8 \\
\hline 11. & probability & no & 5 & ... that an event & 2 \\
\hline 12. & event & no & 33 & uncertain ... & 9 \\
\hline
\end{tabular}




\begin{tabular}{|c|c|c|c|c|c|}
\hline 13. & $\begin{array}{c}\text { event } \\
\text { condition }\end{array}$ & no & $\begin{array}{l}3 \\
2 \\
\end{array}$ & uncertain ... & 1 \\
\hline 14. & function & no & 6 & $\begin{array}{c}\ldots \text { of the likelihood } \\
\text { of a loss weighted by } \\
\text { its severity }\end{array}$ & $\begin{array}{l}7 \text { likelihood } \\
2 \text { severity }\end{array}$ \\
\hline 15. & measure & no & 3 & $\begin{array}{c}\text {... of future } \\
\text { uncertainties }\end{array}$ & 5 uncertainties \\
\hline 16. & $\begin{array}{c}\text { factor } \\
\text { element } \\
\text { constraint } \\
\text { course of action }\end{array}$ & no & $\begin{array}{l}3 \\
7 \\
1 \\
1 \\
\end{array}$ & $\begin{array}{c}\text {... that introduces an } \\
\text { uncertainty }\end{array}$ & $\begin{array}{c}4 \\
\text { uncertainty }\end{array}$ \\
\hline 17. & $\begin{array}{c}\text { event } \\
\text { condition }\end{array}$ & no & $\begin{array}{l}9 \\
2\end{array}$ & uncertain ... & 3 \\
\hline 18. & assessment & no & 104 & $\begin{array}{c}\text {... of the potential } \\
\text { inability }\end{array}$ & $\begin{array}{c}3 \\
\text { inability } \\
\end{array}$ \\
\hline 19. & event & no & 26 & uncertain & 12 \\
\hline 20. & $\begin{array}{c}\text { event } \\
\text { condition }\end{array}$ & no & $\begin{array}{l}9 \\
3 \\
\end{array}$ & -- & -- \\
\hline 21. & factor & no & 4 & any $\ldots$. & 6 \\
\hline 22. & $\begin{array}{c}\text { event } \\
\text { condition }\end{array}$ & no & 10 & uncertain ... & 13 \\
\hline 23. & $\begin{array}{c}\text { event } \\
\text { condition }\end{array}$ & no & $\begin{array}{c}13 \\
7\end{array}$ & uncertain ... & 12 \\
\hline 24. & $\begin{array}{c}\text { event } \\
\text { condition }\end{array}$ & no & $\begin{array}{c}48 \\
3\end{array}$ & uncertain ... & 5 \\
\hline
\end{tabular}

Source: The author's calculations

None of the sources, except one, provides the definition of the decisive concept. In one of the sources (source No. 7), there is a definition of 'risk event'. 'Risk event' is used three times in the source, i.e., in one definition of 'risk event'. The concepts of 'risk event' and 'event', which are used in the definition of 'risk', cannot be considered the same because the decisive concept of 'risk event' is 'discrete occurrence'.

Three most common decisive concepts - 'event', 'condition', 'chance' - were chosen for further research. The total number of sources was 14. Because of the size limitations of the publication, the author chose two sources by using a random number generator (www.random.org). The first decisive concept was 'chance' (source No. 4), the decisive concepts in the second one were 'event' and 'condition' (source No. 17). As none of the selected concepts was defined in the sources, the author performed analysis of the concept use and the results of the analysis were compared with the generally accepted concept definitions in authoritative dictionaries.

The analysis of the source (source No.4) with AntConc shows that the concept of 'chance' is used 22 times, the frequency of use is at the top of the list it ranks $730-755^{\text {th }}$ out of 5630 occurrences, or different words. The concept of 'chance' is used in $0.02 \%$, or 22 words out of 110 173. Compared to the concept 'risk' with $2.4 \%$ and concept 'risks', $0.9 \%$, the concept of 'chance' is not common. In the text of the source, 'chance' is distributed evenly with just one place with a more intensive use (see Fig. 1). The concept 'chance' is most common in chapter 11 "Managing Opportunities". 


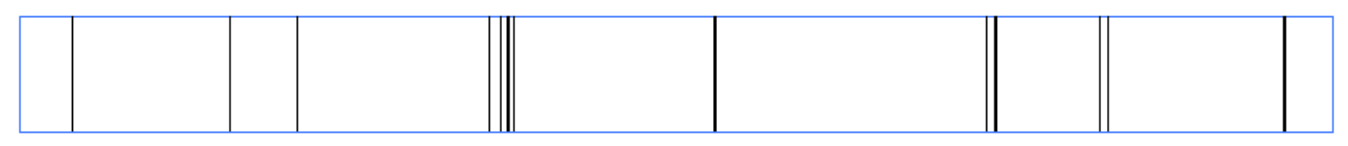

Fig. 1. The frequency of use of the concept 'chance' (Developed by the author using AntConc).

The concept 'chance' was used in 21 sentences about risks. In order to assess the compliance of the concept of 'chance' to the generally accepted use as defined in authoritative dictionaries, Table 4 summarizes the definitions of 'chance' from several dictionaries.

Table 4. Definitions of 'chance' from several dictionaries

\begin{tabular}{|c|c|}
\hline Dictionary & Definitions of 'chance' in dictionaries and a comment \\
\hline $\begin{array}{l}\text { Cambridge } \\
\text { Dictionary }\end{array}$ & $\begin{array}{l}\text { 1. an occasion that allows something to be done } \\
\text { 2. the level of possibility that something will happen } \\
\text { 3. a possibility that something negative will happen } \\
\text { 4. the force that causes things to happen without any known cause or reason } \\
\text { for doing so }\end{array}$ \\
\hline $\begin{array}{l}\text { English Oxford } \\
\text { Living } \\
\text { Dictionaries }\end{array}$ & $\begin{array}{l}\text { 8. A possibility of something happening } \\
\text { 9. The probability of something desirable/.1 happening } \\
\text { 10. An opportunity to do or achieve something } \\
\text { 11. The occurrence of events in the absence of any obvious intention or cause }\end{array}$ \\
\hline $\begin{array}{l}\text { Macmillan } \\
\text { Dictionary }\end{array}$ & $\begin{array}{l}\text { 12. an opportunity for you to do something, especially something that you } \\
\text { want to do } \\
\text { 13. the possibility that something will happen } \\
\text { 14. way things happen without being planned or expected }\end{array}$ \\
\hline $\begin{array}{l}\text { Collins English } \\
\text { Dictionary }\end{array}$ & $\begin{array}{l}\text { 15. the unknown and unpredictable element that causes an event to result in a } \\
\text { certain way rather than another, spoken of as a real force } \\
\text { 16. the extent to which an event is likely to occur; probability }\end{array}$ \\
\hline
\end{tabular}

Source: The author's selection from dictionaries

The dictionary definitions were numbered and the source sentences using 'chance' were analyzed according to the definitions (see Table 5).

Table 5. Concept 'chance' analyzed according to the definitions

\begin{tabular}{|c|c|c|}
\hline Use of concept 'chance' in the source & $\begin{array}{l}\text { No. of } \\
\text { the } \\
\text { defi- } \\
\text { nition }\end{array}$ & Comments \\
\hline $\begin{array}{l}\text { In project management context, it is the } \\
\text { chance of something happening that will have } \\
\text { an impact upon objectives (the sentence is } \\
\text { used } 3 \text { times in defining 'risk', twice in the } \\
\text { text and once in the glossary) }\end{array}$ & $\begin{array}{c}1,5 \\
\text { (partly) }\end{array}$ & $\begin{array}{l}\text { According to the Cambridge } \\
\text { Dictionary, "chance" is "something } \\
\text { to be done" and "something will } \\
\text { happen" "of something happening" } \\
\text { is unnecessary in the source } \\
\text { definition because it is a part of the } \\
\text { concept "chance'. }\end{array}$ \\
\hline $\begin{array}{l}\text { This can be a problem in practice, as there is a } \\
\text { chance that significant risks may go unnoticed }\end{array}$ & & $\begin{array}{l}\text { N/a because the use of the concept } \\
\text { 'chance' is n/a concerning 'risk'. }\end{array}$ \\
\hline
\end{tabular}




\begin{tabular}{|c|c|c|}
\hline $\begin{array}{l}\text { The earlier version identifies items with high } \\
\text { likelihoods or high consequences or both, so } \\
\text { the chance of high consequence but low } \\
\text { likelihood items being ignored is reduced } \\
\text { greatly }\end{array}$ & $\begin{array}{l}2,7,8 \\
9,13 \\
16\end{array}$ & $\begin{array}{l}\text { Concepts 'likelihoods' and } \\
\text { 'consequences' are not used in the } \\
\text { definitions of 'risk', although } \\
\text { 'consequences' can be referred to } \\
\text { the "impact upon objectives" part } \\
\text { of the definition of 'risk'. }\end{array}$ \\
\hline $\begin{array}{l}\text { When considering opportunities, the } \\
\text { likelihood scale need not change, as this } \\
\text { reflects the chance of a beneficial outcome }\end{array}$ & & $\begin{array}{l}\text { N/a because the use of the concept } \\
\text { 'chance' is n/a concerning 'risk'. }\end{array}$ \\
\hline $\begin{array}{l}\text { Changing the likelihood of the opportunity, to } \\
\text { increase the chance of beneficial outcomes }\end{array}$ & 2,3 & $\begin{array}{l}\text { Concepts 'likelihoods', } \\
\text { 'opportunities' and 'outcomes' are } \\
\text { not used in the definitions of 'risk', } \\
\text { although "outcomes" can be } \\
\text { referred to the "impact upon } \\
\text { objectives" part of the definition of } \\
\text { 'risk'. }\end{array}$ \\
\hline $\begin{array}{l}\text { After opportunities have been changed or } \\
\text { shared, there may be residual opportunities } \\
\text { that are retained with no further immediate } \\
\text { action specified. This may be described as } \\
\text { 'leaving it to chance' }\end{array}$ & & $\begin{array}{l}\text { N/a because the use of the concept } \\
\text { 'chance' is } \mathrm{n} / \mathrm{a} \text { concerning 'risk'. }\end{array}$ \\
\hline $\begin{array}{l}\text { The likelihood here was the chance of } \\
\text { realizing the benefit within the available } \\
\text { budget, either during the contract negotiation } \\
\text { process or as part of project implementation }\end{array}$ & & $\begin{array}{l}\text { N/a because the concept 'chance' is } \\
\text { used for defining another concept. }\end{array}$ \\
\hline $\mathrm{XY}$ axis "Chance of meeting the target" & 10,14 & $\begin{array}{l}\text { The author assumed that the } \\
\text { concept 'chance' is used as a } \\
\text { synonym to 'risk'. }\end{array}$ \\
\hline $\begin{array}{l}\text { The graph shows the way in which the chance } \\
\text { of achieving the target (on the vertical axis) } \\
\text { increases as the cost target (on the horizontal } \\
\text { axis) increases }\end{array}$ & 10,14 & $\begin{array}{l}\text { The author assumed that the } \\
\text { 'chance' concept is used as a } \\
\text { synonym to 'risk'. }\end{array}$ \\
\hline $\begin{array}{l}\text { This is relatively conservative }- \text { it implies } \\
\text { only a } 10 \% \text { chance of failure to achieve the } \\
\text { cost target }\end{array}$ & 2,9 & $\begin{array}{l}\text { The author believes that the concept } \\
\text { 'chance' in the sentence does not } \\
\text { coincide with the same concept in } \\
\text { the definition of 'risk'. }\end{array}$ \\
\hline $\begin{array}{l}\text { The vertical line A shows the dollar value of } \\
\text { the most recent cost estimate: the results } \\
\text { indicated slightly more than a } 50 \% \text { chance the } \\
\text { project could be completed within this amount }\end{array}$ & 2,9 & $\begin{array}{l}\text { The author believes that the concept } \\
\text { 'chance' in the sentence does not } \\
\text { coincide with the same concept in } \\
\text { the definition of 'risk'. }\end{array}$ \\
\hline $\begin{array}{l}\text { Line B shows the estimate including the } \\
\text { original contingency allowance: the results } \\
\text { indicated a } 90 \% \text { chance of completing the } \\
\text { project within this budget under normal } \\
\text { conditions }\end{array}$ & 2,9 & $\begin{array}{l}\text { The author believes that the concept } \\
\text { 'chance' in the sentence does not } \\
\text { coincide with the same concept in } \\
\text { the definition of 'risk'. }\end{array}$ \\
\hline $\begin{array}{l}\text { In this case, there was a } 5 \% \text { chance of a } \\
\text { variation less than }-10 \% \text {, and a } 5 \% \text { chance } \\
\text { of a variation over }+10 \%\end{array}$ & 2,9 & $\begin{array}{l}\text { The author believes that the concept } \\
\text { 'chance' in the sentence does not } \\
\text { coincide with the same concept in } \\
\text { the definition of 'risk'. }\end{array}$ \\
\hline $\begin{array}{l}\text { For example, there was a } 20 \% \text { chance that a } \\
\text { labour site allowance might be imposed on } \\
\text { Stage } 1 \text { construction, which would have the } \\
\text { effect of increasing Stage } 1 \text { construction costs } \\
\text { by } 30 \%\end{array}$ & 2,9 & $\begin{array}{l}\text { The author believes that the concept } \\
\text { 'chance' in the sentence does not } \\
\text { coincide with the same concept in } \\
\text { the definition of 'risk'. }\end{array}$ \\
\hline
\end{tabular}




\begin{tabular}{|l|l|l|}
\hline $\begin{array}{l}\text { This was a simple assumption for modelling, } \\
\text { but it gave appreciable weight to the extreme } \\
\text { values within distributions where there was a } \\
\text { long tail, i.e. where there was a chance of a } \\
\text { large deviation from the most likely cost } \\
\text { outcome }\end{array}$ & 2,9 & $\begin{array}{l}\text { The author believes that the concept } \\
\text { 'chance' in the sentence does not } \\
\text { coincide with the same concept in } \\
\text { the definition of 'risk'. }\end{array}$ \\
\hline $\begin{array}{l}\text { There was a small chance the return would be } \\
\text { negative }\end{array}$ & 2,9 & $\begin{array}{l}\text { The author believes that the concept } \\
\text { 'chance' in the sentence does not } \\
\text { coincide with the same concept in } \\
\text { the definition of 'risk'. }\end{array}$ \\
\hline $\begin{array}{l}\text { The central line is the mean outcome forecast } \\
\text { by the model; the band on either side is the } \\
\text { range in which the outcome is expected with } \\
90 \% \text { chance }\end{array}$ & 2,9 & $\begin{array}{l}\text { The author believes that the concept } \\
\text { of 'chance' in the sentence does not } \\
\text { coincide with the same concept in } \\
\text { the definition of 'risk'. }\end{array}$ \\
\hline $\begin{array}{l}\text { The extent to which an event is likely to } \\
\text { occur; mathematically, a probability is a } \\
\text { number in the scale } 0 \text { to } 1 \text { that refers to the } \\
\text { chance of a random event occurring }\end{array}$ & $\begin{array}{l}\text { N/a because 'chance' is used in the } \\
\text { definition of another concept. }\end{array}$ \\
\hline
\end{tabular}

Source: The author's valuation

According to the analysis of the source (source No. 17) with AntConc, the concept of 'event' is used 9 times, the frequency of its use ranks at the top of the list, between $458^{\text {th }}-499^{\text {th }}$ of 2675 ranks or different words. The concept of 'event' is used in $0.03 \%$, or 9 words out of 27063 . Compared to $3.8 \%$ of the concept 'project', $1.2 \%$ of 'management', 'schedule' with $0.6 \%$ and 'risk', $0.4 \%$, the concept of 'event' is not often used. In the source text 'event' is used in individual places and it is distributed evenly over the text (see Fig. 2).

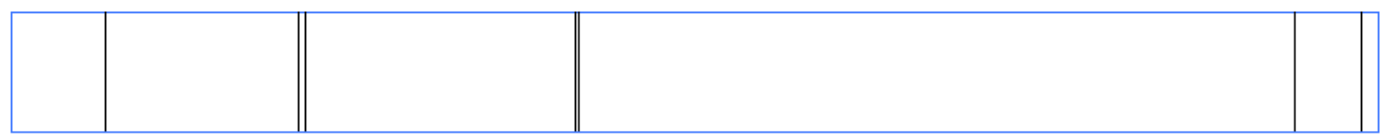

Fig. 2. The frequency of use of the concept of 'event' (source No. 17) (Developed by the author using AntConc)

According to the analysis of the source (source No. 17) with AntConc, the concept of 'events' is used 11 times, the frequency of its use ranks at the top of the list, between $384^{\text {th }}-416^{\text {th }}$ of 2675 ranks or different words. The concept of 'events' is used in $0.04 \%$, or 11 words of 27063 . Compared to 'project', 'management', 'schedule' with $0.6 \%$ and 'risk', $0.4 \%$, the concept of 'events' is not often used. In the source text, 'events' is used in individual places and it is distributed evenly over the text (see Fig. 3).

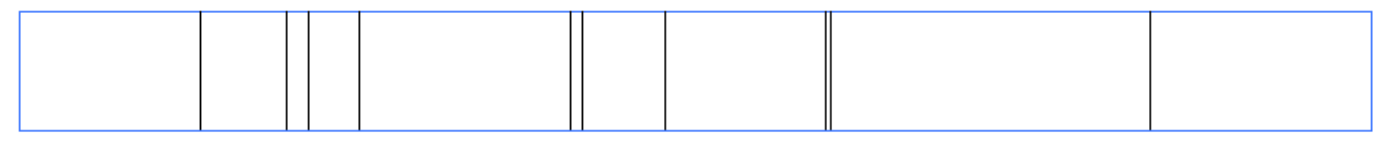

Fig. 3. The frequency of use of the concept of 'events' (source No. 17)

(Developed by the author using AntConc) 
The concept 'event' is used in 5 sentences and in 4 sentences about risks. To assess the compliance of the concepts 'event' and 'events' with the standard use as indicated in authoritative dictionaries, Table 6 summarizes the definitions of 'event' from several dictionaries.

Table 6. Definitions of 'event' from several dictionaries

\begin{tabular}{|c|c|}
\hline Dictionary & Definitions of 'event' in dictionaries \\
\hline $\begin{array}{l}\text { Cambridge } \\
\text { Dictionary }\end{array}$ & 1. anything that happens, especially something important or unusual \\
\hline $\begin{array}{l}\text { English Oxford } \\
\text { Living } \\
\text { Dictionaries }\end{array}$ & 2. A thing that happens or takes place, especially one of importance. \\
\hline $\begin{array}{l}\text { Macmillan } \\
\text { Dictionary }\end{array}$ & $\begin{array}{l}\text { 3. something that happens, especially something that involves several people } \\
\text { 4. events [plural] used in a general way to talk about a combination of things } \\
\text { that happen }\end{array}$ \\
\hline $\begin{array}{l}\text { Collins English } \\
\text { Dictionary }\end{array}$ & $\begin{array}{l}\text { 5. An event is something that happens, especially when it is unusual or } \\
\text { important. You can use events to describe all the things that are happening in } \\
\text { a particular situation. } \\
\text { 6. the actual or final outcome; result. } \\
\text { 7. an occurrence regarded as a bare instant of space-time as contrasted with an } \\
\text { object which fills space and has endurance. } \\
\text { 8. an occurrence regarded in isolation from, or contrasted with, human agency. }\end{array}$ \\
\hline
\end{tabular}

Source: The author's selection from dictionaries

The dictionary definitions were numbered and the sentences of the source where 'event' is used were analyzed in accordance with the definitions (see Table 7).

Table 7. Accordance with the definitions

\begin{tabular}{|c|c|c|}
\hline Use of 'event' and 'events' in the source & $\begin{array}{l}\text { No. of the } \\
\text { definition }\end{array}$ & Comments \\
\hline \multicolumn{3}{|c|}{ Concept 'event' } \\
\hline $\begin{array}{l}\text { Project risk is an uncertain event or condition } \\
\text { that, if it occurs, has a positive or negative } \\
\text { effect on at least one project objective }\end{array}$ & $1,2,5$ & $\begin{array}{l}\text { Coincides with the definitions of } \\
\text { 'event' concerning happening and } \\
\text { importance. }\end{array}$ \\
\hline $\begin{array}{l}\text { Whenever possible, the PM takes action to } \\
\text { lessen the probability of a risk event } \\
\text { occurring, or the impact to the project if it } \\
\text { does occur }\end{array}$ & $1,2,5$ & $\begin{array}{l}\text { Coincides with the definitions of } \\
\text { 'event' concerning happening and } \\
\text { importance. }\end{array}$ \\
\hline $\begin{array}{l}\text { Set in motion the plan to manage the issues } \\
\text { that are the outcome of a risk event occurring, } \\
\text { and use the Issues Tracking Log }\end{array}$ & 6 & \\
\hline $\begin{array}{l}\text { Project risk is an uncertain event or condition } \\
\text { that, if it occurs, has a positive or negative } \\
\text { effect on at least one project objective, such } \\
\text { as time, cost, scope, or quality (i.e. where the } \\
\text { project time objective is to deliver in } \\
\text { accordance with the agreed upon schedule; } \\
\text { when the project cost objective is to deliver } \\
\text { within the agreed upon costs; etc.) }\end{array}$ & $1,2,3,5,6$ & $\begin{array}{l}\text { Coincides with the definitions of } \\
\text { 'event' concerning happening and } \\
\text { importance, the definition of 'risk' } \\
\text { in the source is more specific as it } \\
\text { contains information on project } \\
\text { management in particular areas. }\end{array}$ \\
\hline
\end{tabular}




\begin{tabular}{|l|l|l|}
\hline $\begin{array}{l}\text { The risk event is that the permitting agency } \\
\text { may take longer than planned to issue a } \\
\text { permit, or the design personnel available and } \\
\text { assigned may not be adequate for the activity }\end{array}$ & $\begin{array}{l}\text { Although the concept 'event' is } \\
\text { used in the source sentence, it is } \\
\text { still not clear why there is the } \\
\text { concept 'risk event" as well, is } \\
\text { there any difference from 'event' } \\
\text { used in the 'risk' definition. }\end{array}$ \\
\hline \multicolumn{2}{|c|}{ Concept 'events' } \\
\hline $\begin{array}{l}\text { Monitor and track risk events and status } \\
\text { implemented smoothly? }\end{array}$ & $\begin{array}{l}\text { The compliance with the } \\
\text { dictionary definitions of 'event' } \\
\text { cannot be identified. }\end{array}$ \\
\hline $\begin{array}{l}\text { The objectives of Project Risk Management } \\
\text { are to increase the probability and impact of } \\
\text { positive events, and decrease the probability } \\
\text { and impact of events adverse to the project }\end{array}$ & $1,2,3,5$ & $\begin{array}{l}\text { The compliance with the } \\
\text { dictionary definitions of 'event' } \\
\text { cannot be identified. }\end{array}$ \\
$\begin{array}{l}\text { The compliance with the } \\
\text { dictionary definitions of 'event' } \\
\text { cannot be identified unanimously } \\
\text { as in the source sentence there are } \\
\text { concepts not used in the } \\
\text { definitions (probability, impact, } \\
\text { positive, and adverse) }\end{array}$ \\
\hline $\begin{array}{l}\text { If either of these uncertain events occurs, } \\
\text { there may be an impact on the project cost, } \\
\text { schedule, or performance }\end{array}$ & $1,2,3,5$ & \multicolumn{1}{|c|}{} \\
\hline
\end{tabular}

Source: Compiled by the author

According to the analysis of the source using AntConc, the concept 'condition' is used twice, there is low frequency of use, $1238^{\text {th }}-1652^{\text {th }}$ rank out of 2675 or different words. The concept of 'condition' is used in $0.01 \%$, or one word out of 27063 words. In comparison with the concepts of 'project', 'management', 'schedule' with $0.6 \%$ and 'risk', $0.4 \%$, the concept of 'condition' is used seldom (see Fig. 4).

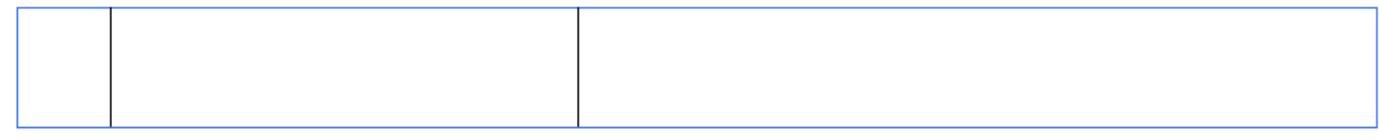

Fig. 4. The frequency of use of the concept of 'condition' (source No. 17) (Developed by the author using AntConc)

In order to evaluate the compliance of the concept of 'condition' with the standard use as defined by authoritative dictionaries, Table 8 summarizes the definitions of 'condition' provided in the dictionaries. In both cases 'condition' is used in defining 'risk'. This was the reason why it was useless to analyze the use of 'condition' in the source sentences. The author compared the dictionary definitions of 'event' and 'condition' to understand why two decisive concepts of 'risk' were used in the definition. 
Table 8. Accordance with the definitions of 'event' and 'condition'

\begin{tabular}{|l|l|l|}
\hline \multicolumn{1}{|c|}{ Dictionary } & \multicolumn{1}{|c|}{$\begin{array}{c}\text { Definitions of the concept 'condition' in } \\
\text { dictionaries and a comment }\end{array}$} & $\begin{array}{c}\text { Comparison of the } \\
\text { dictionary definitions of } \\
\text { 'event' and 'condition'. }\end{array}$ \\
\hline $\begin{array}{l}\text { Cambridge } \\
\text { Dictionary }\end{array}$ & $\begin{array}{l}\text { 1. the particular state that something or } \\
\text { someone is in } \\
\text { 2. an arrangement that must exist before } \\
\text { something else can happen }\end{array}$ & $\begin{array}{l}\text { Both concepts differ by the } \\
\text { time category and share the } \\
\text { fact of happening. }\end{array}$ \\
\hline $\begin{array}{l}\text { English Oxford } \\
\text { Dictionaries }\end{array}$ & $\begin{array}{l}\text { 3. The state of something with regard to its } \\
\text { appearance, quality, or working order } \\
\text { 4. The factors or prevailing situation } \\
\text { influencing the performance or outcome of a } \\
\text { process. }\end{array}$ & $\begin{array}{l}\text { There is no match with the } \\
\text { f. A situation that must exist before something } \\
\text { else is possible or permitted. }\end{array}$ \\
\hline $\begin{array}{l}\text { Macmillan } \\
\text { Dictionary }\end{array}$ & $\begin{array}{l}\text { 7. the physical state of something } \\
\text { something happens or exists }\end{array}$ \\
\hline $\begin{array}{l}\text { Collins English } \\
\text { Dictionary }\end{array}$ & $\begin{array}{l}\text { 8. particular state of being or existence; } \\
\text { situation with respect to circumstances } \\
\text { 9. external or existing circumstances } \\
\text { 10. something indispensable to the existence of } \\
\text { something else } \\
\text { 11. anything essential to the existence or } \\
\text { occurrence of something else; prerequisite } \\
\text { 12. anything that modifies or restricts the } \\
\text { nature, existence, or occurrence of something } \\
\text { else; external circumstance or factor }\end{array}$ & $\begin{array}{l}\text { There is no match with the } \\
\text { definition of 'event'. }\end{array}$ \\
\hline
\end{tabular}

Source: The author's selection from dictionaries and valuation

The author believes that the concepts of 'event' and 'condition' are not similar by their content according to the dictionary definitions. 'Condition' could be one of the significant decisive concepts in defining the content of 'risk'. However, taking into account that the concept of 'condition' is used twice in the source definitions of 'risk', the methods used in the research are not sufficient for assessing the necessity for the concept of 'condition' in the definition of 'risk'.

\section{CONCLUSION}

The ontological analysis of the sources on project risk management covering the definitions of the concepts provided by the authors of the sources has been conducted, answering the question if the defined concepts are existing, i.e., if by defining the concepts in the sources it is confirmed that the phenomena described by the concepts exist. It is important for the cases when phenomena have to be identified by the concept definitions, for example, to identify risks in project management that will later be followed by risk analysis and management.

The author believes that the conducted research helps establish confidence that ontological analysis is the method that together with the epistemological analysis (Uzulāns, 2017) can be used to perform analysis of the sources on risk management aimed at improving risk management. In the previous research the author stated, 
"The content of the concepts of 'event' and 'uncertainty' is very different and maybe the analysis of the ontological, epistemological and methodological and real project risk register of the definitions of 'event' and 'uncertainty' will provide the analysis, which reveals relationships, which could not be identified by the methods used in previous studies (Uzulāns, 2017)." The ontological, epistemological and methodological analysis of the definitions of the concept 'risk' is the theoretical foundation for creation of risk register because it is possible to create complete and understandable register for the participants of the project risk management process. The definitions of the concept 'risk' include information about decisive concept or concepts and about limiters of the decisive concept that facilitates risk identification and analysis. Correct use of the concepts and limiters that are used in the definitions of the concept 'risk' can promote development of project risk management documents, which might be an applicable register for all participants of the project risk management process.

The author believes that the content of the concept 'risk' is determined by several decisive concepts, which either specify, narrow down or widen the content of the concepts. It can be assumed that the authors of the definitions believe that this is the way how to define the concept of 'risk' better or more precisely. However, considering that science requires precise definition of the basic concepts, the listing of several decisive concepts cannot provide for a more complete and precise definition, if the source does not contain definitions of the decisive concepts or the decisive concepts are not used in the source text or are not used frequently enough to make conclusions about the content of the concepts. For example, just one dictionary - Collins English Dictionary - contains the rationale why the concepts of 'event' and 'condition' are the decisive concepts of 'risk'.

However, the results of the study cannot be considered sufficient for deriving valid conclusions about project risk management and developing recommendations for improving risk management with regard to the content of the risk register. For valid conclusions and recommendations a deeper research is needed which, first of all, would analyze a larger number of sources. Secondly, the origin of the sources might be considered along with the dictionary definitions of the respective country or the dictionaries, which contain corresponding definitions of the concept, such as Collins English Dictionary. Thirdly, when analyzing definitions, an additional analysis of synonyms should be performed paying attention to the part of speech. Fourthly, during the study the author found that the qualitative research methods used have to be improved by creating a formal set of criteria that will allow for performing the selection and analysis of the sentences, which contain the examined concepts. Similarly, a set of formal criteria is necessary for the selection of the dictionary definitions. The four dictionaries used in the study provide several definitions for the concepts of 'chance', 'event' and "condition" and it is important to make the correct choice among them. 


\section{REFERENCES}

Association for Project Management. (2006). APM Body of Knowledge (5th ed.). Buckinghamshire: Association for Project Management.

Chapman, C., \& Ward, S. (2003). Project Risk Management. Processes, Techniques and Insights (2nd ed.). Chichester: John Wiley \& Sons Ltd.

Cooper, D., Grey, S., Raymond, G., \& Walker, P. (2005). Project Risk Management Guidelines. Managing Risk in Large Projects and Complex Procurements. Chichester: John Wiley \& Sons Ltd.

City Of Tampa - Department of Technology and Innovation. (n.d.). City Of Tampa Project Management Guidebook: City Of Tampa - Department of Technology and Innovation. 32.p.

Department of Defense. (2006). Risk Management Guide for DOD Acquisition (6th ed.). U.S.: Defense Technical Information Center.40 p.

Department of Transportation. (2017). Risk Management Guideline. New Jersey: Department of Transportation.Retrieved

from http://www.state.nj.us/transportation/capital/pd/documents/RiskManagementGuideline.pdf

European Commission. (2004). Project Cycle Management Guidelines. Brussels: European Commission. Retrieved from https://ec.europa.eu/europeaid/sites/devco/files/methodology-aid-delivery-methodsproject-cycle-management-200403_en_2.pdf

International Labour Organization. (2015). Development Cooperation Manual. Public version. Geneva: ILO. Retrieved from http://www.ilo.org/wcmsp5/groups/public/---dgreports/--exrel/documents/publication/wcms_452076.pdf

Kerzner, H. (2009). Project Management. A Systems Approach to Planning, Scheduling, and Controlling (10th ed.). New Jersey: John Wiley \& Sons, Inc.

Larson, E., \& Gray, C. (2011). Project Management. The Managerial Process (5th ed.). New York: The McGraw-Hill/Irwin.

Method123 empowering managers to succeed. (2003). Project Management Guidebook. Method123. Retrieved from http://www.method123.com/affiliates/method123-ebook.pdf

Missouri Information Technology Advisory Board. (2003). Risk Management: Guidelines and Best Practices. Missouri Information Technology Advisory Board.

ND Enterprise Project Management Advisory Group. (2009). North Dakota Project Management Guidebook. Risk Management Supplement. ND Enterprise Project Management Advisory Group. Retrieved from https://www.nd.gov/itd/sites/itd/files/legacy/services/pm/risk-management-guidebook.pdf

Ohara, S. (2005). Guidebook of Project \& Program Management for Enterprise Innovation. Volume II. Project Management Professionals Certification Center. Retrieved from https://articulospm.files.wordpress.com/2013/01/p2mguidebookvolume1_060112.pdf

PM4NGOs. (2013). A Guide to the PMD Pro. PM4NGOs. Retrieved from http://www.pm4ngos.com/wpcontent/uploads/2015/05/PMD_Pro_Guide_2e_EN_USLetter.pdf

Program Management Office (PMO). (2002). Risk Management Guidelines. Georgia: Georgia Technology. Retrieved from http://www.google.lv/url?sa=t\&rct=j\&q=\&esrc=s\&source=web\&cd=1\&ved=0ahUKEwjR7ojh_fLYAhV UFMAKHd9UBLsQFggmMAA\&url=http $\% 3 \mathrm{~A} \% 2 \mathrm{~F} \% 2 \mathrm{Fgta}$.georgia.gov\%2Fsites\%2Fgta.georgia.gov\%2 Ffiles\%2Fimported\%2Fvgn\%2Fimages\%2Fportal\%2Fcit_1210\%2F3\%2F50\%2F65747052GTA-PMOGLI-202\%2520Risk\%2520Management\%2520Guideline.doc\&usg=AOvVaw27ZGr7R9bNx8rWCSfY8yb

Official PM Book for AAPM (2014). International Project Management Commission \& The American Academy of Project Management (IPMC \& AAPM). (n.d.). AAPM IPMC Project Management Handbook for Managers \& Executives. Retrieved from http://certifiedprojectmanager.us/AAPM-Book-Study-Guide2014.pdf

Organization for Security and Co-operation in Europe. (2010). Project Management in the OSCE. Vienna: Organization for Security and Co-operation in Europe, OSCE Secretariat. Retrieved from http://www.osce.org/secretariat/70693?download=true

U.S. Department of Energy. (2004). Project Control Handbook. U.S: Department of Energy. Retrieved from https://www.slideshare.net/haroldtaylor1113/project-control-handbook

U.S. Department of Justice. (2015). Information Technology (IT) Project Manager Guide. US: Department of Justice. Retrieved from https://www.justice.gov/jmd/file/705781/download

U.S. Department of Transportation. (2016). Project and Construction Management Guidelines. US: Department of $\quad$ Transportation. $\quad$ Retrieved from https://www.transit.dot.gov/sites/fta.dot.gov/files/docs/FTA_Project_and_Construction_Mgmt_Guideline s_2016.pdf 
U.S. Government Accountability Office (GAO). (2015). Schedule Assessment Guide. Best Practises for Project Schedules. US: Government Accountability Office (GAO). Retrieved from https://www.gao.gov/assets/680/674404.pdf

Uzulāns, J. (2017). The Epistemological Analysis of the Concept "Risk" and Project Risk Management. Riga: University of Latvia. Retrieved from http://pmworldjournal.net/wp-content/uploads/2017/10/pmwj63Oct2017-Uzulans-epistemological-analysis-of-risk-second-edition.pdf

The American Institute of Architects. (2007). Integrated Project Delivery: A Guide. Retrieved from https://info.aia.org/SiteObjects/files/IPD_Guide_2007.pdf

Transportation Research Board. (2010). Guidebook on Risk Analysis Tools and Management Practices to Control Transportation Project Costs. Washington: Transportation Research Board. Retrieved from http://www.trb.org/Publications/Blurbs/163722.aspx

\section{AUTHOR'S SHORT BIOGRAPHY}

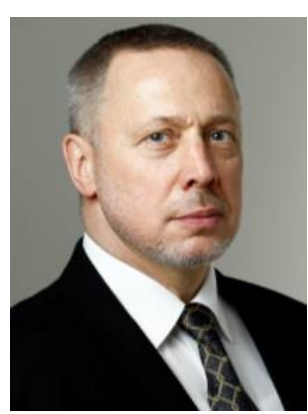

Juris Uzulāns is lecturer in in BA School of Banking and Finance. He possesses more than 15 years of experience in theoretical and practical project management. It includes managing projects in the state governance, health care system, institutions of higher education and IBM Latvia.

The author has designed and delivered courses in project management in BA School of Banking and Finance, Latvian School of Public Administration as well as commercial firms specialized in training.

In science the author focuses on risk management, analysis of project processes and documentation. Juris is author of 4 books on project management and 20 scientific publications.

E-mail: jouris@latnet.lv 